\title{
Acute mucosal pathogenesis of feline immunodeficiency virus is independent of viral dose in vaginally infected cats
}

\author{
Kristina E Howard ${ }^{1 *}$, Stacie K Reckling ${ }^{1}$, Erin A Egan ${ }^{1,2}$, Gregg A Dean
}

\begin{abstract}
Background: The mucosal pathogenesis of HIV has been shown to be an important feature of infection and disease progression. HIV-1 infection causes depletion of intestinal lamina propria CD4+ T cells (LPL), therefore, intestinal CD4+ T cell preservation may be a useful correlate of protection in evaluating vaccine candidates. Vaccine studies employing the cat/FIV and macaque/SIV models frequently use high doses of parenterally administered challenge virus to ensure high plasma viremia in control animals. However, it is unclear if loss of mucosal T cells would occur regardless of initial viral inoculum dose. The objective of this study was to determine the acute effect of viral dose on mucosal leukocytes and associated innate and adaptive immune responses.

Results: Cats were vaginally inoculated with a high, middle or low dose of cell-associated and cell-free FIV. PBMC, serum and plasma were assessed every two weeks with tissues assessed eight weeks following infection. We found that irrespective of mucosally administered viral dose, FIV infection was induced in all cats. However, viremia was present in only half of the cats, and viral dose was unrelated to the development of viremia. Importantly, regardless of viral dose, all cats experienced significant losses of intestinal CD4+ LPL and CD8+ intraepithelial lymphocytes (IEL). Innate immune responses by CD56+CD3- NK cells correlated with aviremia and apparent occult infection but did not protect mucosal T cells. CD4+ and CD8+ T cells in viremic cats were more likely to produce cytokines in response to Gag stimulation, whereas aviremic cats T cells tended to produce cytokines in response to Env stimulation. However, while cell-mediated immune responses in aviremic cats may have helped reduce viral replication, they could not be correlated to the levels of viremia. Robust production of anti-FIV antibodies was positively correlated with the magnitude of viremia.

Conclusions: Our results indicate that mucosal immune pathogenesis could be used as a rapid indicator of vaccine success or failure when combined with a physiologically relevant low dose mucosal challenge. We also show that innate immune responses may play an important role in controlling viral replication following acute mucosal infection, which has not been previously identified.
\end{abstract}

\section{Background}

The recent failure of the STEP clinical trial of the MRKAd5 HIV-1 gag/pol/nef vaccine has raised important questions about vaccine development for HIV-1 [1-3]. Participants in the Phase I trial had robust measurable $\mathrm{T}$ cell responses to vaccination [4]; similar robust $\mathrm{T}$-cell responses were observed in participants in the Phase IIB trial, however, they afforded no protection

\footnotetext{
* Correspondence: KEHoward25@gmail.com

${ }^{1}$ Center for Comparative Medicine and Translational Research, Department of Molecular Biomedical Sciences, College of Veterinary Medicine, North Carolina State University, Raleigh, NC, 27606, USA
}

against HIV-1 infection as compared to the control group [5]. These data suggest that measurable in vitro $\mathrm{T}$ cell responses of the participants were not a reliable predictor of vaccine protection. Identification of appropriate and reliable correlates of protection has been elusive in pathogenesis and vaccine studies. Many potential immunologic correlates have been suggested including cytotoxic CD8+ T cells, neutralizing antibodies, and preservation of memory and effector lymphocyte populations in the gastrointestinal mucosa [6]. However, numerous studies examining the role of $\mathrm{T}$ cell and antibody responses in the protection of highly-exposed

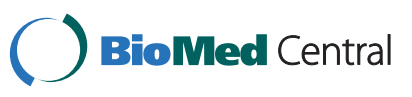

(c) 2010 Howard et al; licensee BioMed Central Ltd. This is an Open Access article distributed under the terms of the Creative Commons
Attribution License (http://creativecommons.org/licenses/by/2.0), which permits unrestricted use, distribution, and reproduction in

(c) 2010 Howard et al; licensee BioMed Central Ltd. This is an Open Access article distributed under the terms of the Creative Commons
Attribution License (http://creativecommons.org/licenses/by/2.0), which permits unrestricted use, distribution, and reproduction in any medium, provided the original work is properly cited. 
persistently seronegative (HEPS) individuals, and control of viral replication in elite controllers (EC) and longterm non-progressors (LTNP) [7-12], have yielded conflicting results [13-16].

Collectively, these observations raise new questions about defining correlates of protection and how they could be more clearly distinguished in the context of future vaccine trials $[17,18]$. Further, as animal model vaccine trials appeared to show the MRKAd5 vaccine to be protective [19-23], the design and assumptions used in animal model vaccine trials might also need to be reconsidered.

Vaccine studies using animal models often employ high doses of challenge virus to ensure a high viral set point in control animals so that a reduction of viral burden in vaccinated animals can be used as an indicator of efficacy. Unfortunately, high challenge doses do not mimic natural infection and could lead to flawed conclusions about the true efficacy of a vaccine [24]. The majority of HIV-1 infections occur via the mucosal route [25]. Certain studies suggest that infection can occur in serodiscordant couples with repeated sexual exposure from their HIV-1 positive partners who have plasma viral loads ranging from 5-400 copies/ml [26]. These observations suggest that high viral challenge doses are not physiologically relevant in natural HIV transmission. Further, animal model studies have shown that low dose infection can result in either productive or latent infection [27-31]. In contrast, several investigators have suggested that low viral dose may be partially responsible for individuals who are either HEPS or LTNP [32-34]. Importantly, the effect of initial viral dose on the presence and severity of mucosal pathogenesis is unclear, in particular when the route of infection is via the reproductive mucosa. Therefore, a better understanding of the relationship between viral dose, mucosal pathogenesis and mucosal immune response would enhance our ability to design and interpret vaccine trials.

In the present study, we employed the well-described cat/feline immunodeficiency virus (FIV) model [35-39] to investigate the relationship between viral dose and immune pathogenesis. We vaginally challenged three groups of cats with different infectious doses of cellassociated and cell-free FIV to determine the effect of viral dose on mucosal leukocyte populations. To address possible correlates of protection, we assessed the role of innate, cell-mediated, and humoral immune responses in acute FIV infection to determine if any of these immune responses were associated with decreased viral dissemination and protection of the gastrointestinal mucosa. These studies provide new insight into early mechanisms of control over viral replication, with particular emphasis on the responses in the mucosa.

\section{Results}

Viral load

Cats vaginally infected with high, middle, or low doses of cell-associated and cell-free virus were evaluated for viral load by PCR and virus isolation. Figure 1 summarizes mean plasma viral load for each group. Peak viremia was detected at four weeks post-infection in all groups, with plasma viremia detected in 4/6 high (range, $2.2 \times 10^{4}$ to $2.0 \times 10^{3}$ copies $/ \mathrm{ml}$ plasma), $3 / 6$ middle (range, $1.8 \times 10^{4}$ to $1.5 \times 10^{2}$ copies $/ \mathrm{ml}$ plasma) and $2 / 5$ low (range, $2.4 \times 10^{4}$ to $1.7 \times 10^{2} \mathrm{copies} / \mathrm{ml}$ plasma) dose inoculated cats. Provirus in PBMC was detected in 3/6 high, 1/6 middle and 2/5 low dose inoculated cats. Virus was isolated from unfractionated bone marrow in 5/6 high, 5/6 middle, and 5/5 low dose inoculated cats. By at least one of these measures, each cat, regardless of inoculum dose, was infected with FIV. Interestingly, although shown to be infected, eight cats did not have detectible plasma viremia.

Effect of FIV infection on CD4+ and CD8+ T cell numbers Two weeks post-infection, absolute CD4+ T cell numbers in PBMC (Figure 2A) were decreased in the high ( $\mathrm{p}$ $=0.002)$ and middle $(p=0.06)$ dose groups, whereas the low dose group experienced a modest decrease by four weeks post-infection that was not significant. All three groups had comparable mean CD $4+\mathrm{T}$ cell numbers at study end; mean levels which were lower than pre-infection levels. Importantly, the presence or absence of viremia was not correlated with absolute CD4+ T cell numbers (Figure 2B). All dose groups had similar reductions in CD4:CD8 ratio over the course of the study (Figure 2C).

No significant changes in CD4+ T cell percentages were observed in PBMC, lymph nodes, spleen or thymus for any group (Figure 3), however, a significant decrease in LPL CD4+ T cell percentages, averaging a 57\% loss as compared to control cats, was noted regardless of

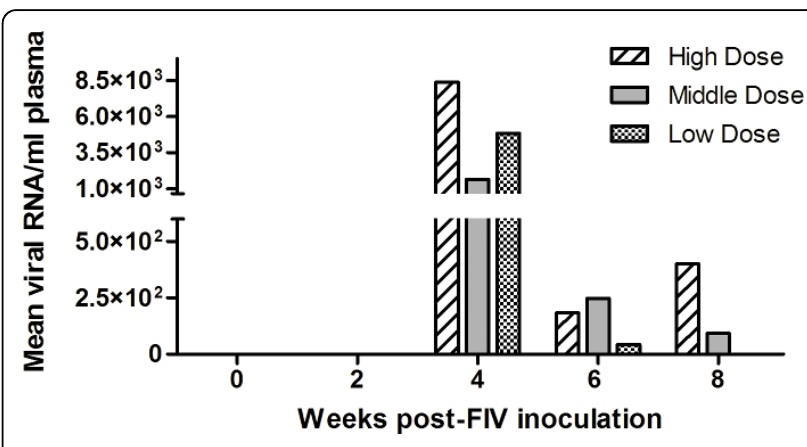

Figure 1 Mean plasma viral RNA. Plasma from blood sampled at weeks $0,2,4,6$ and 8 post-infection was evaluated for viral RNA using real-time PCR. Mean viral RNA copies per $\mathrm{ml}$ of plasma are shown for high, middle and low dose groups. 
A.

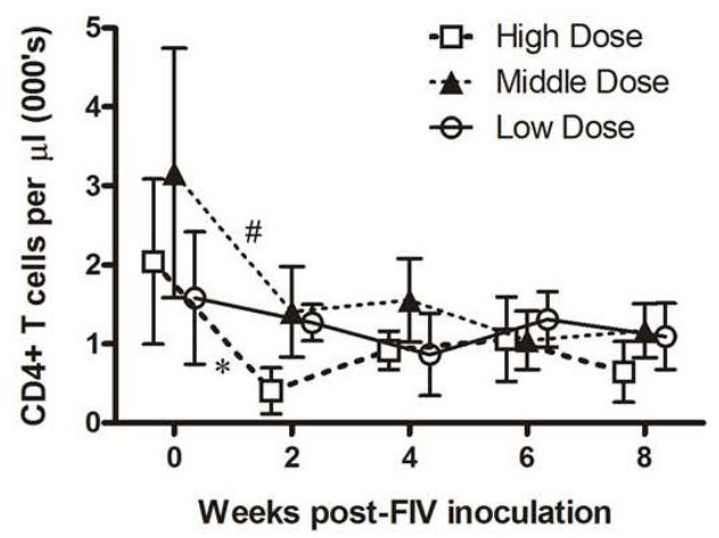

B.

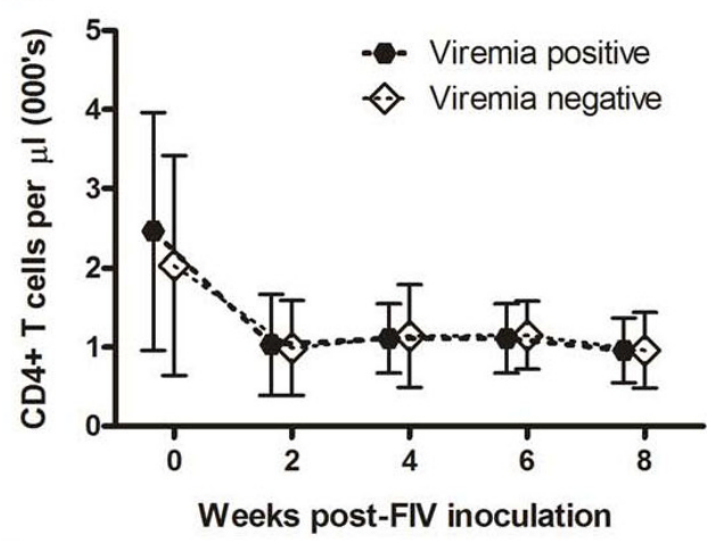

C.

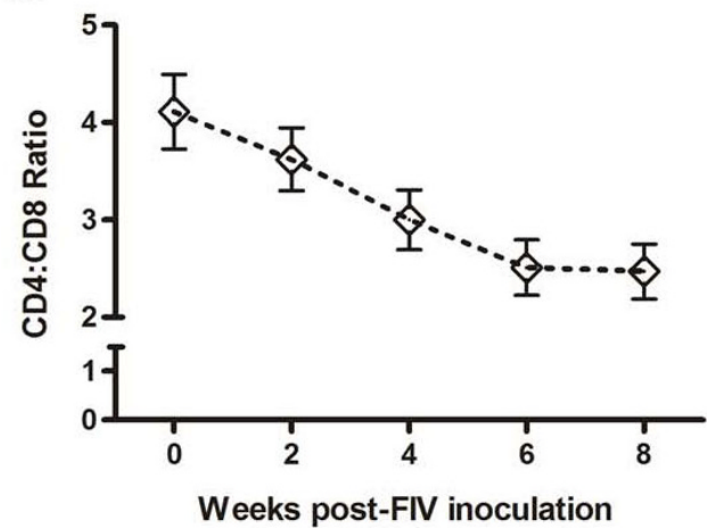

Figure 2 Absolute CD4+ T cell count in PBMC. Blood sampled at weeks $0,2,4,6$ and 8 post-infection was evaluated for phenotypic expression of CD4+ T cells and calculated based on total WBC counts with differential cell count assessed from cytological evaluation. Mean and standard deviation for absolute CD4+ T cell counts are presented for high, middle and low dose groups (A), and based on presence or absence of viremia (B). Mean and standard errors for the $C D 4: C D 8$ ratio are shown for all dose groups combined (C). Statistics were calculated using ANOVA comparing baseline week with post-infection samples within each group. Significance shown using $p$-values, with ${ }^{*} p<0.01$ and $\# p=0.06$ inoculum dose (Figure 4A). The loss of CD4+ LPL was further magnified considering a significant loss in total yield of LPL occurred (mean control LPL yield was 6.80 $\times 10^{7}$ vs. FIV-infected LPL yield of $3.94 \times 10^{7}, \mathrm{p}=$ 0.00037). Furthermore, a significant decrease in the percentage of CD8 $\alpha+$ and $C D 8 \beta+\mathrm{T}$ cells was found in IEL from all dose groups as compared to controls (Figure $4 B, C)$. As CD $8 \alpha \alpha+$ and $C D 8 \alpha \beta+T$ cells serve different functions in the epithelial compartment, we also assessed if either of these populations was specifically lost. $C D 8 \alpha \beta+\mathrm{T}$ cells were significantly decreased in all dose groups, compared to controls (ANOVA, p < $0.001)$. CD $8 \alpha \alpha+\mathrm{T}$ cell percentages were not significantly decreased in FIV-infected cats ( $p=0.1311)$, however, the overall trend showed decreased percentages in FIV-infected cats [18.11\%] versus controls [24.85\%].

\section{Innate immune response}

While all study cats were infected with FIV, a few cats in each dose group did not become viremic. To identify immunologic populations that might mediate the apparent control of viremia, we assessed total NK cells (CD56 $+\mathrm{CD} 3+/-)$, classic NK cells (CD56+CD3-) and NKT cells $(\mathrm{CD} 56+\mathrm{CD} 3+)$ in blood, draining lymph node (data not shown), spleen, and IEL. Total CD56+ NK cell expression was significantly decreased in FIV-infected cats as compared to control cats in each site at eight weeks post infection (Figure. 5A). Figure 5(B) and 5(C) show NKT cell and classic NK cell percentages, respectively, in viremic, non-viremic and control cats. NKT cell percentages were significantly reduced in PBMC and spleen from FIV-infected cats, regardless of viremia status. In contrast, CD56+CD3- NK cells were significantly decreased only in viremic cats.

\section{Cell-mediated immune responses}

Anti-Gag and anti-Env specific CD4+ and CD8+ T cell responses were assessed in $\mathrm{PBMC}$, peripheral and draining lymph nodes, spleen, IEL and LPL (Figure. 6 and data not shown). Cells were stimulated for six hours with peptide pools for Gag and Env [40], and then intracellular IL-2, IFN $\gamma$, and TNF $\alpha$ production was determined in CD4+ and CD8+ T cells. No differences in cytokine production were found when comparing groups based on inoculum dose (data not shown). Differences in IFN $\gamma$ and IL-2 production were compared on the basis of presence or absence of viremia.

Responses in viremic cats tended to be directed to Gag rather than Env peptides, whereas non-viremic cats had a similar magnitude of response to both Gag (data not shown) and Env peptides. Significant differences were noted in viremic cats when comparing the production of IFN $\gamma$ by CD4+ and CD8+ T cells from the lamina propria in response to Gag versus Env peptides. 


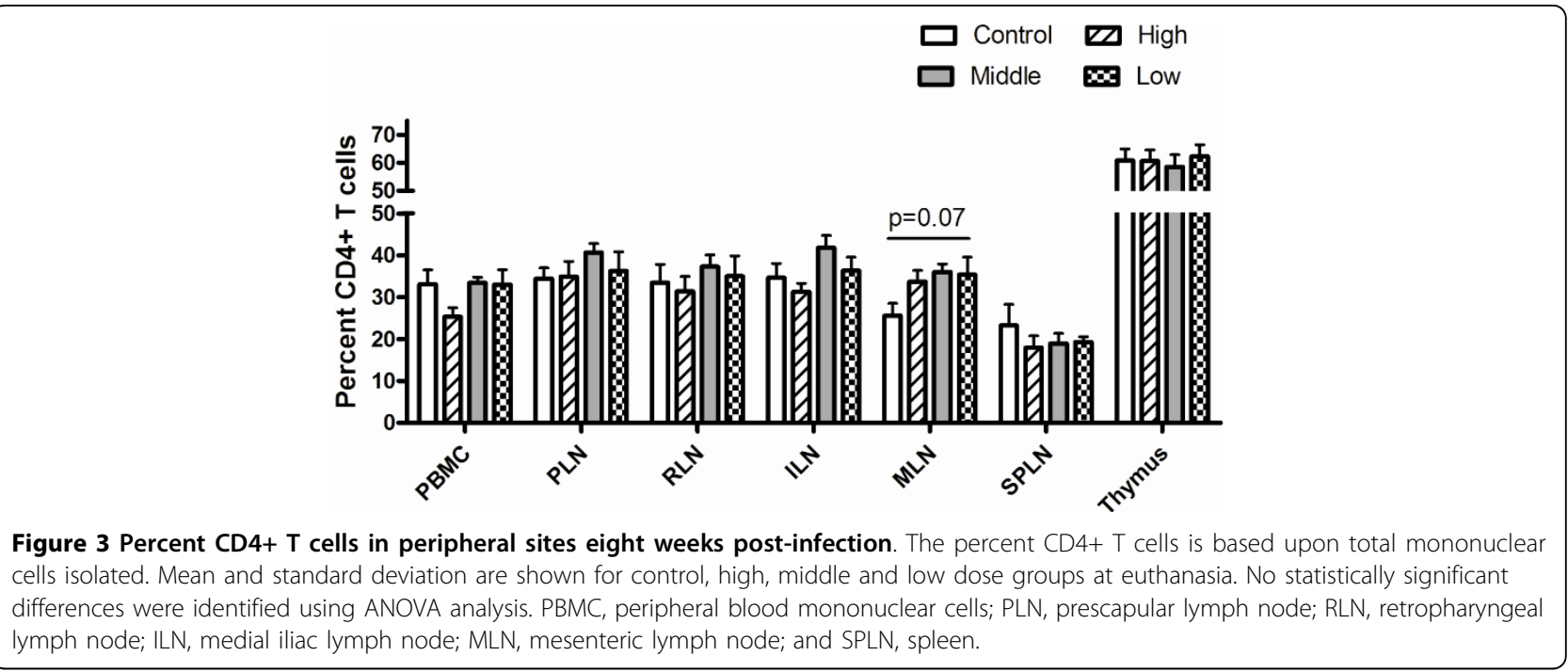

This trend was also evident in CD4+ and CD8+ LPL, which produced both IL-2 and IFN $\gamma$ against Gag peptides, but not Env peptides.

FIV-infected, non-viremic cats were more likely to produce cytokines in response to Env peptide stimulation as compared to viremic cats. This was evident in CD4+ and CD8+ IFN $\gamma$ specific responses in LPL, IL-2 responses in the draining lymph node (ILN), and IL-2 $+\mathrm{IFN} \gamma+$ producing cells in the ILN. Compared to viremia positive cats, non-viremic cats also showed significant differences in anti-Env responses in CD4+ IL-2 producing PBMC. CD8+ IL-2 producing PBMC also showed a marked difference $(p=0.06)$. The trend of anti-Env responses was also identified in CD4+IL-2 $+\mathrm{IFN} \gamma+\mathrm{LPL}$ and CD8+IL-2+IFN $\gamma+$ splenocytes.

\section{Humoral immune responses}

To understand the contribution humoral immunity may have played in control of viremia, we assessed anti-Gag and anti-Env responses in serum and vaginal wash samples using a highly sensitive chemiluminescent ELISA assay. Two cats did not produce antibodies against either Gag or Env, three cats produced antibodies only to Env, and six cats produced anti-Gag antibodies at levels that would not be detectable using a commercial diagnostic test for FIV. The remaining six cats produced substantial titers to Gag and/or Env (Table 1). Almost all Gag and Env specific viral titers in vaginal wash were less than 1:256 or below the limit of detection for either IgA or IgG. Thus, using our highly sensitive ELISA, 88\% of the cats seroconverted.

\section{Immune responses associated with control of viremia}

Given the trends identified for innate, cell-mediated and humoral responses, we next determined if any of these responses correlated with control of viremia. In Figure 7, Spearman correlations are shown for NK cell subsets (A), draining lymph node and LPL production of IL-2 and IFN $\gamma$ by CD4 and CD8 T cells (B), and serum Gag and Env titers $(C)$.

Significant inverse correlations to viremia were identified in both PBMC and Spleen CD56+CD3- NK cells, with $r=-0.51$ and $r=-0.52$ respectively (Figure 7A). Cell mediated responses in the draining lymph node suggested a trend associated with anti-Env responses in CD4 and CD8 T cells producing IL-2, however this was not significant. Surprisingly, a significant positive correlation with viremia was identified for LPL CD4 T cells producing IL-2 in response to Gag $(\mathrm{r}=0.51)$. Additional trends suggested $\mathrm{T}$ cell responses to Env in LPL may be associated with viral control; however, these correlations were not significant (Figure 7B). Antibody titers significantly correlated with the presence and magnitude of viremia, with anti-Env $(r=0.77)$ and anti-Gag $(r=$ 0.48 ). These correlations indicate that higher serum titers to Env (and Gag to a lesser degree) positively correlated with the degree of peak viremia (Figure 7C).

\section{Discussion}

Parameters of viral challenge are an important consideration in animal model pathogenesis and vaccine studies. The majority of human HIV-1 infections occur via the reproductive mucosa and frequently involve cellassociated and cell-free forms of virus [41-43]. Further, leukocyte numbers present in a single human semen sample can range from $1.0 \times 10^{4}$ to $1.0 \times 10^{8}$, resulting in a potentially significant number of HIV-infected leukocytes in seminal fluid [44-46]. The biological relevance of cell-free, high viral dose inocula administered intravenously or intrarectally is questionable [24]. A goal 


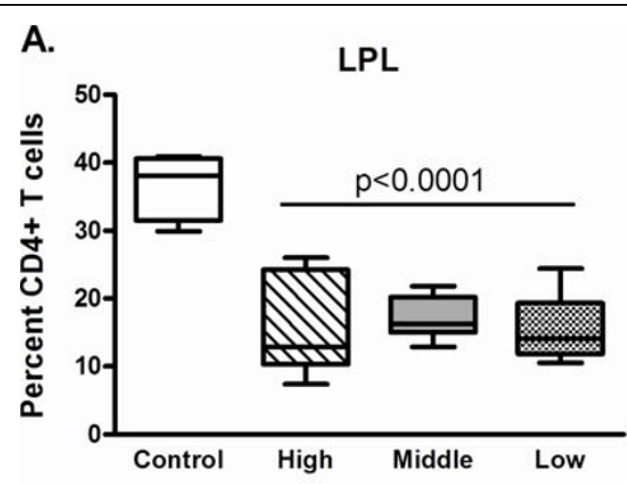

B.

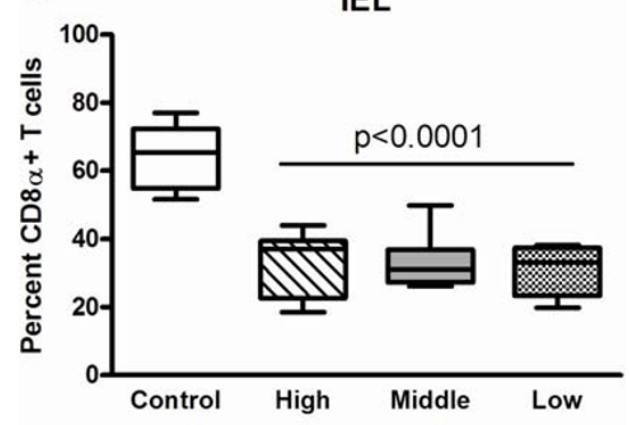

C. IEL

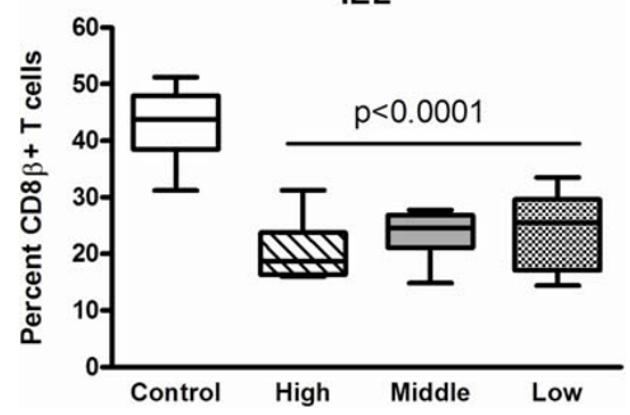

Figure 4 Alterations in mucosal lymphocyte populations eight weeks post-infection. Box and whisker plots show the median with upper and lower quartile represented by the boxes, and minimum and maximum values shown by the whiskers. Percent of CD4+ T cells in LPL (A), CD8 $\alpha+T$ cells in IEL (B), and CD8 $\beta+T$ cells in IEL (C) are shown for control, high, middle and low dose groups at euthanasia. Statistical significance was calculated using ANOVA, with $\mathrm{p}$-value shown for FIV-infected groups compared to controls.

of the present study was to mimick the inoculum diversity found during natural HIV infection and to administer the inoculum via the reproductive mucosa. Results showed that a relatively low dose of cell-free and cellassociated virus administered vaginally caused infection in all, yet viremia in only half of the cats. Moreover, viral dose was unrelated to the development of viremia. Importantly, regardless of the presence of viremia, all infected cats had significant changes in mucosal $\mathrm{T}$ cell populations, suggesting that a low dose challenge may be sufficient to test vaccine efficacy if mucosal pathology is used as a primary correlate of protection.

For obvious reasons there is great interest in individuals with transient or controlled HIV-1 infection (thoroughly reviewed by Shacklett)[47]. Some studies have suggested that seronegative persons with high risk of exposure to HIV-1 may avoid infection as a result of low viral dose exposure [30,31]. In the present study, peak viremia was of similar magnitude regardless of dose, and there were cats in each dose group that did not become viremic. Thus, while virus dose undoubtedly plays a role in the likelihood of infection and viremia, the relationship is not linear and individual immune responses may be critical.

Of course, determination of virologic status depends on the sensitivity of methods used and tissue compartments that are evaluated. Clinically measurable seroconversion was only evident in $1 / 8$ non-viremic cats, suggesting that these cats have occult infection. In this study, we used whole bone marrow, which has been shown to be a site of latency in FIV and other retroviral infections [48-51], to isolate virus. This method has been shown to be more sensitive in detecting low levels of retrovirus than standard real-time PCR techniques used to identify proviral integration in PBMC [52]. If standard clinical techniques had been used to determine the presence of infection, 6/17 cats would have been categorized as exposed and seronegative. As postulated by several authors and supported by our results, occult or latent infection, controlled by innate and cellmediated immunity may occur more frequently in highly-exposed individuals than is currently recognized [30,31,53-56].

This study also comprehensively evaluated innate, cellmediated and humoral immunity. NK cells are an important innate immune defense, particularly against intracellular pathogens [57], as they recognize virus infected cells without requiring costimulatory signals from other immune system cells, such as dendritic cells. Given their importance in clearing viral infection, we assessed the prevalence of total NK, classic (CD56 +CD3-) and NKT cells in PBMC, lymph node and tissues. Decreased NK cell percentages, in general, and NKT cells, specifically, were associated with FIV infection while classic NK cells were preserved in non-viremic cats. A significant negative correlation was identified for CD56+CD3- NK cells and viremia that suggests innate immunity may play a greater role in control of acute retroviral infection than previously believed. Our results are consistent with prior observations of peripheral CD56+ NK cell loss in HIV-infected patients [58]. These results are supported by a study that showed increased NK cell function in highlyexposed seronegative injecting Vietnamese drug users as 


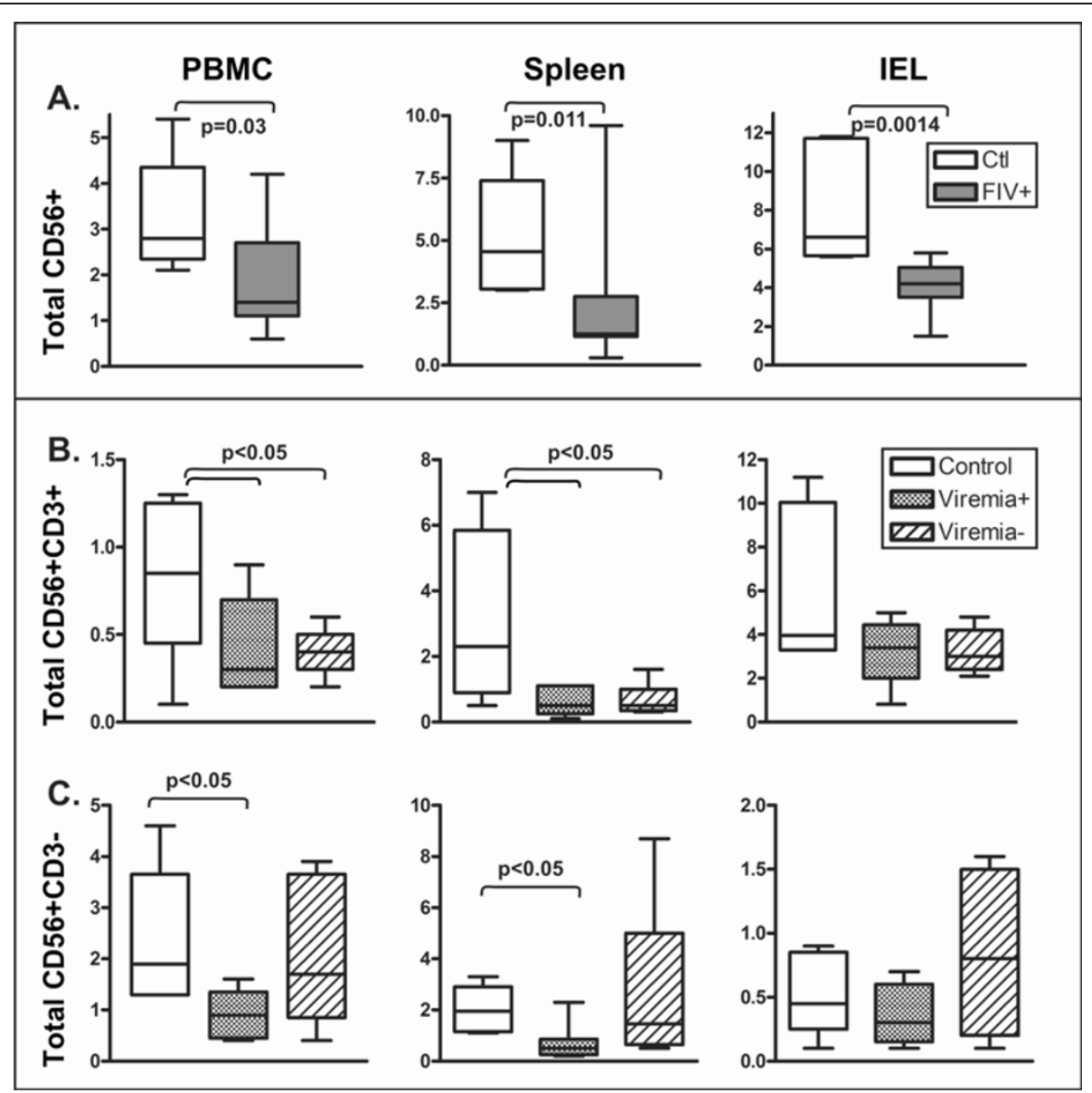

Figure 5 NK cell subsets eight weeks post-infection. Percent NK cells (CD56+) in PBMC, Spleen and IEL for all dose groups of FIV-infected cats versus control cats (A). Percent of NKT cells (B) and classic NK cells (C) are shown based presence or absence of viremia versus control cats. Box and whisker plots show the median with upper and lower quartile represented by the boxes, and minimum and maximum values shown by the whiskers. Statistics were calculated using an unpaired t-test in (A), and based on ANOVA in (B) and (C), with significance shown using pvalues where differences were identified.

compared to individuals who eventually seroconverted [59]. However, a recent study that examined in vitro NK cell function of elite controllers suggested a more limited role for NK cells in control of viral replication [60]. A limitation of the present study is that the effector function of NK and CD8 $+\mathrm{T}$ cells was not evaluated using an in vitro killing assay. It is also important to note that increased presence of a specific population, e. g. NK cells, does not necessarily correlate with their ability to kill virally infected cells. Therefore, additional evaluation of NK cell frequency and function in HEPS, EC and LTNP is needed to better understand their role and the mechanisms used to control viral replication.

As numerous studies have shown an important role for cell-mediated immunity in HIV-1 control, we anticipated $\mathrm{T}$ cell function would be correlated with reduced viremia. However, correlation of IFN- $\gamma$ and IL-2 production by $\mathrm{CD} 4+$ and $\mathrm{CD} 8+\mathrm{T}$ cells yielded surprising results. A positive correlation to viremia was found for LPL CD4+ T cell production of IL-2 in response to Gag stimulation, with a similar trend observed for CD8+ LPL producing IL-2. In addition, while trends for inverse correlation with viremia were present for draining lymph node and LPL responses to Env stimulation, none were significant. This is in spite of significant differences in cytokine production when comparing viremic and non-viremic cats. Further, tissue specific cytokine responses in LPL were evident. Viremic cats were more likely to produce IFN $\gamma$ and IL-2 against Gag peptides, whereas non-viremic cats produced IFN $\gamma$ and IL-2 against Env peptides. However, these responses were insufficient to prevent the loss of CD4+ LPL and CD8+ IEL in non-viremic cats. However, we cannot dismiss the possibility that these cytokine responses may have helped reduce mucosal viral reservoirs, preventing widespread viral dissemination and viremia. As has been 


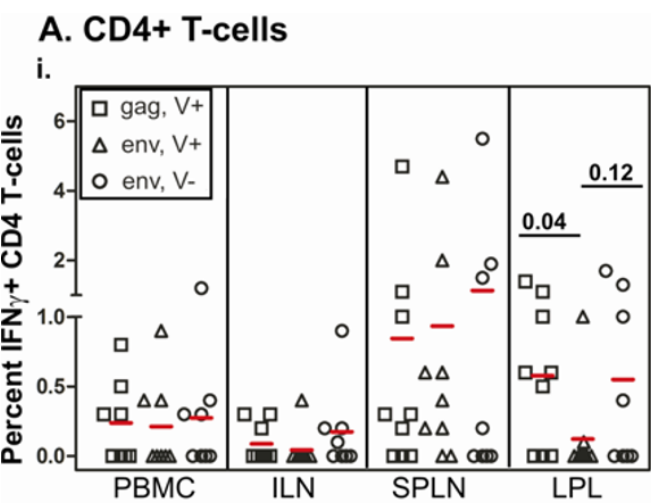

ii.

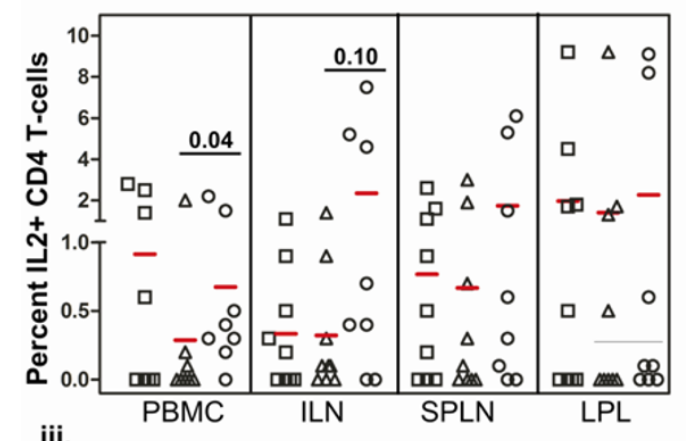

iii.

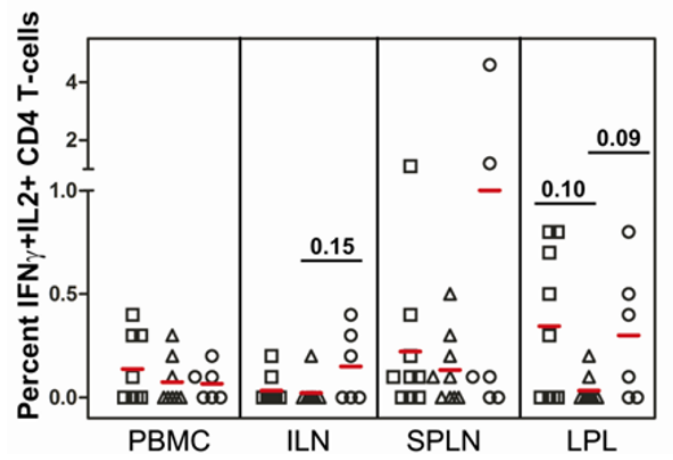

\section{B. CD8+ T-cells}

i.

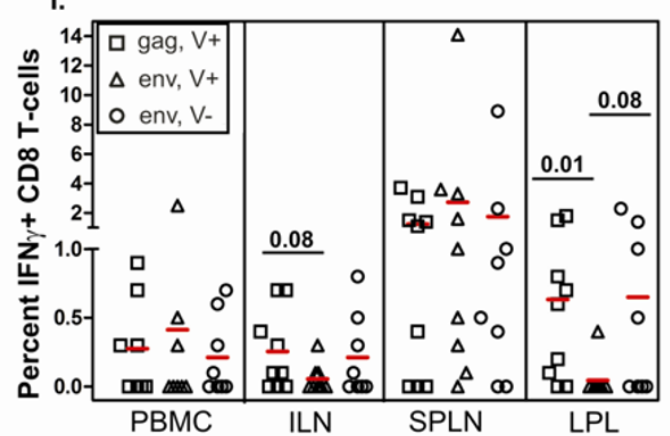

ii.

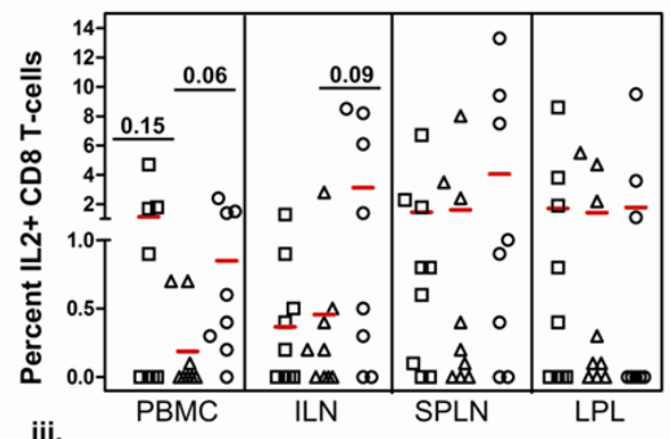

iii.

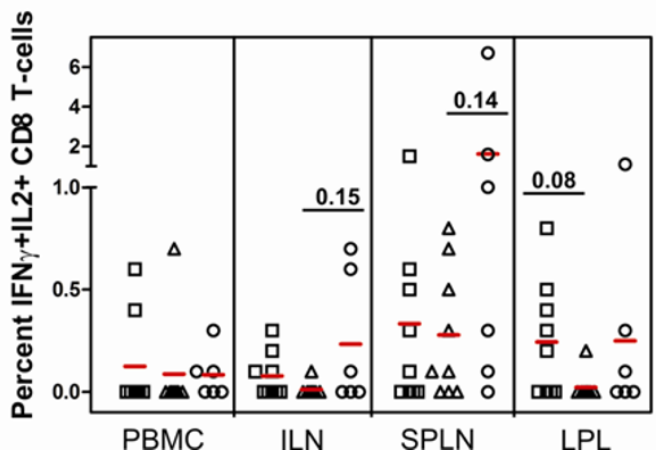

Figure 6 Intracellular cytokine expression of IFN $\gamma$ and IL-2 by CD4+ and CD8+ T cells eight weeks post-infection. Expression of IFN $\gamma$ is shown in the top panels, IL-2 in the middle panels and dual expressing (IFN $\gamma+\mathrm{IL}-2+$ ) in the bottom panels for CD4+ T cells (A) and CD8+ T cells (B). Individual data points are shown with mean expression indicated by a line for each data set. Significant differences in cytokine expression are indicated by a line over the applicable data sets and p-value indicated. Calculations were made using an unpaired t-test.

previously reported, control of viremia or lower viral set points are typically associated with the production of IFN $\gamma$ and IL-2 within the same cell, or are typically associated with the continued ability to produce IL-2 upon stimulation $[7,61,62]$. Our results, similar to Pahar et al. [63] suggest that control of viremia cannot be directly correlated with cell-mediated immunity. Further, Barry et al. [64] showed that depletion of CD8+ T cells in non-pathogenic infection of sooty mangabey monkeys did not play a role in control of viral replication. In addition, others have shown in HIV+ patients that cellmediated immunity did not correctly predict the outcome of infection and AIDS-free survival time $[65,66]$. Collectively, these results suggest that robust cell-mediated immune responses may not be an accurate correlate of protection.

Another surprising result was the strong positive correlation between anti-Env antibody production and the level of viremia. Studies of HIV-1 infected patients and SIV-infected non-human primates have divergent results with respect to anti-Env antibody responses and their role in altering progression of disease course. Some have shown that individuals with profound antibody responses progressed rapidly to AIDS [67-69]. However, 
Table 1 Anti-p24 and anti-Env IgA and IgG antibody responses

\begin{tabular}{|c|c|c|c|c|c|c|c|}
\hline \multirow[b]{2}{*}{ Group } & \multirow[b]{2}{*}{ Cat } & \multicolumn{2}{|c|}{ Vaginal IgA } & \multicolumn{2}{|c|}{$\begin{array}{c}\text { Vaginal } \\
\text { IgG }\end{array}$} & \multicolumn{2}{|c|}{ Serum IgG } \\
\hline & & Gag $^{1}$ & Env & Gag & Env & Gag & Env \\
\hline \multirow[t]{6}{*}{ High Dose } & IQW3 & 128 & 128 & 0 & 32 & $1,048,576$ & 262,144 \\
\hline & IQX7 & 128 & 0 & 0 & 0 & 4,096 & 512 \\
\hline & IRB5 & 0 & 0 & 64 & 0 & 0 & 512 \\
\hline & IRE5 & 0 & 0 & 0 & 256 & 262,144 & $2,097,152$ \\
\hline & $|R| 4$ & 64 & 64 & 64 & 0 & 4,096 & 0 \\
\hline & IRK4 & 64 & 32 & 32 & 0 & 2,048 & 128 \\
\hline \multirow[t]{6}{*}{ Middle Dose } & IQT2 & 0 & 0 & 0 & 0 & 0 & 0 \\
\hline & IQW5 & 0 & 0 & 64 & 64 & 131,072 & 524,288 \\
\hline & IQX6 & 0 & 0 & 256 & 0 & 1,024 & 0 \\
\hline & IRB4 & 0 & 32 & 0 & 0 & 1,024 & 512 \\
\hline & IRE3 & 0 & 0 & 0 & 0 & 0 & 512 \\
\hline & IRK5 & 1,024 & 32 & 256 & 0 & 131,072 & 64 \\
\hline \multirow[t]{5}{*}{ Low Dose } & IQT3 & 32 & 0 & 0 & 0 & 0 & 0 \\
\hline & IQW4 & 4,096 & 128 & 256 & 128 & 262,144 & $2,097,152$ \\
\hline & IRB3 & 32 & 32 & 0 & 0 & 0 & 1,024 \\
\hline & IRK3 & 0 & 0 & 0 & 0 & 65,536 & 0 \\
\hline & IRK6 & 128 & 64 & 256 & 0 & 4,096 & 512 \\
\hline
\end{tabular}

${ }^{1}$ Endpoint titer.

other reports have suggested either a protective association of anti-Env antibodies with HIV-1 disease progression or no discernable pattern at all [70-74]. Our results showed that anti-Env and to a lesser degree anti-Gag antibody responses were associated with measurable infection, rather than occult infection. One possible explanation for this result is that significant levels of antibody were produced as a result of poor control by innate and cell-mediated immunity. Another possibility is that although antibodies were produced at high titers, they may not have been capable of virus neutralization.

Several studies of mucosal pathogenesis in HIV-1 infected humans and SIV infected macaques have focused on depletion of CD4+ LPL, as they are a primary target of infection [75-78]. However, it has been suggested that mucosal immune dysfunction may not be due solely to CD4+ LPL depletion. It has been shown that microbial translocation is a source of chronic antigenic stimulation in HIV infection [79], and that epithelial barrier dysfunction is evident in cellular and molecular processes prior to seroconversion [80]. Given the paucity of studies evaluating the important effector $\mathrm{T}$ cell population present in the epithelium, IEL were evaluated in conjunction with LPL in this study. Our results demonstrated that losses of IEL were as significant as the loss of CD4+ LPL. We have previously shown that CD8+ IEL are significantly depleted as early as one day following FIV infection [81]. The results of the present study suggest these early losses are not transient and occur specifically in the CD $8 \alpha \beta+$ IEL. The combination of their loss with the loss of CD4+ LPL suggests that multiple immunologic factors may be involved in AIDS-associated enteropathy.

A key observation in this study was that all cats, regardless of initial viral dose, experienced profound acute losses in mucosal lymphocyte populations. In a previous study we demonstrated that protected vaccinated cats had mucosal immune populations similar to control cats one year after FIV infection, while unvaccinated cats that were non-viremic had disruptions in their mucosal lymphoid compartment [52]. In addition, non-pathogenic SIV infection of non-human primates has also shown that an initial loss of mucosal lymphocytes occurs, but when examined at later time points, these populations have been restored [82]. Collectively, these findings suggest that mucosal lymphocytes are the most sensitive indicator of infection as they are disrupted regardless of initial viral dose and seroconversion status, indicating that vaccine studies could indeed use preservation of IEL and LPL populations as a correlate of protection.

\section{Conclusions}

In summary, this study provides valuable insight into the immune responses associated with early viral control in FIV infection. We found that NK cells may play a greater role in acute viral control than previously believed; however, other immune responses were associated with the ability of some of these cats to control viremia, and prevent seroconversion. We also show that more attention must be directed to dissecting immune responses not previously addressed in acute pathogenesis, with particular attention to innate immunity. Further, we identified the intestinal mucosa as a very sensitive indicator of retroviral infection that is independent of viral dose and seroconversion. Collectively, our data suggest that low dose challenge may be sufficient to test vaccine efficacy when considering mucosal immune integrity as a primary correlate of protection.

\section{Methods}

\section{Animals and challenge inoculums}

Twenty-three specific pathogen free (SPF) cats were obtained from Liberty Labs (Liberty, NY), group housed and cared for in accordance with AAALAC standards and IACUC guidelines. FIV-infected female cats included high dose $(n=6)$, middle dose $(n=6)$ and low dose $(n=5)$; control cats $(n=6)$ included 4 female and 2 neutered males. Age was six to eighteen months at euthanasia.Cats were infected with cell-associated and cell-free $\mathrm{NCSU}_{1}$, a FIV pathogenic sub-group A virus 


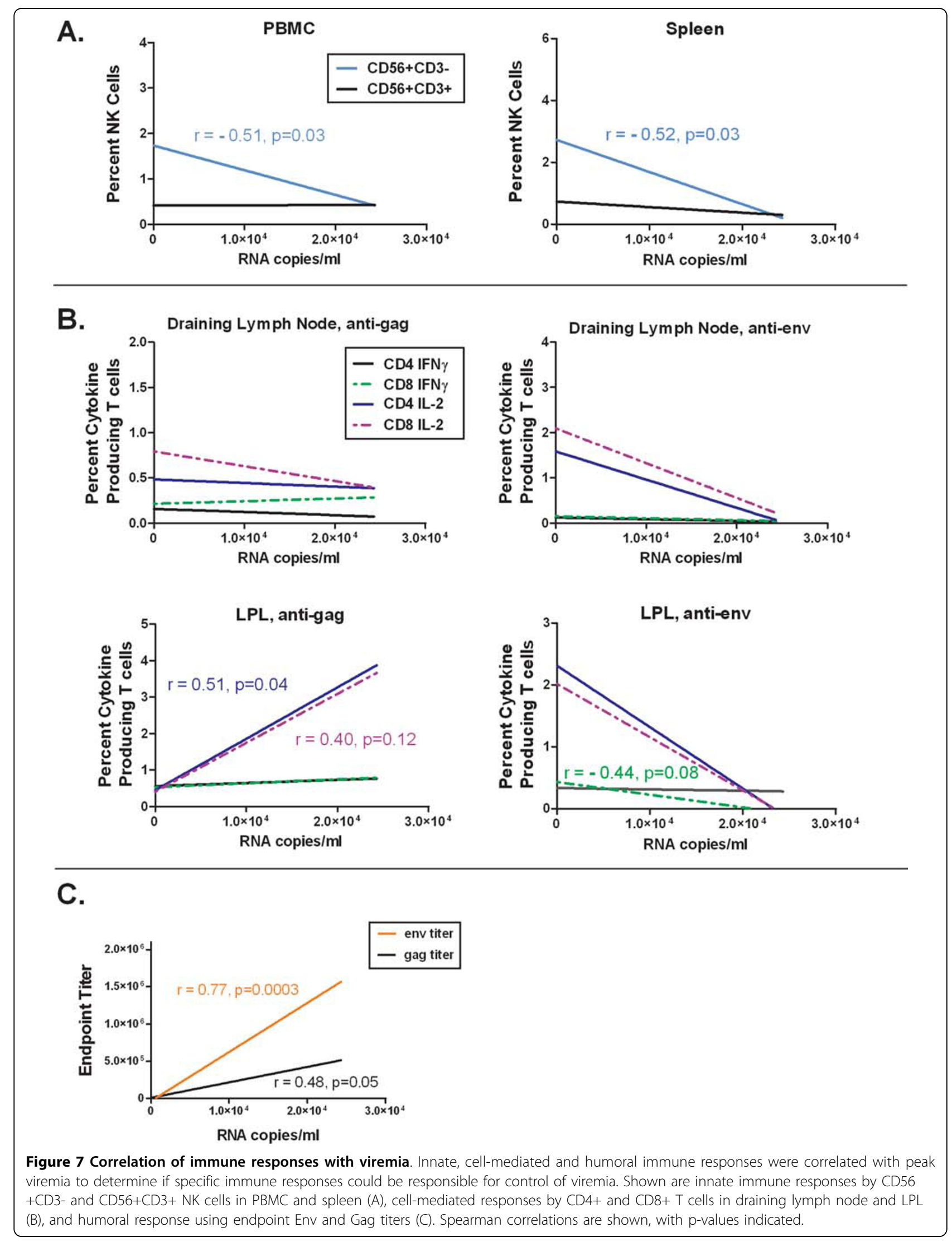


[35]. Cell-associated inoculum was created by intravenously inoculating a SPF cat with FIV-positive cells and harvesting all lymph nodes, spleen, and thymus after six weeks. Lymphocytes obtained were cultured for 7 days to increase the proportion of FIV-positive cells, and then cryopreserved. Supernatants from cultured cells were used to purify cell-free stocks. Cats were intravaginally inoculated with $3.75 \times 10^{5} \mathrm{FIV}$ positive cells and $9.75 \times 10^{4} \mathrm{TCID}_{50}$ cell-free FIV (high dose), $1.88 \times 10^{5}$, FIV positive cells and $4.87 \times 10^{4} \mathrm{TCID}_{50}$ cell-free FIV (middle dose) or $9.3 \times 10^{4}$ FIV positive cells and $2.43 \times$ $10^{4}$ TCID $_{50}$ cell-free inoculum in RPMI, or were unexposed controls. Briefly, cats were sedated and placed in sternal recumbency with a small rolled towel placed under their caudal abdomen to elevate the reproductive tract. Cell-associated and cell-free viral inoculums were combined immediately prior to administration in a sterile microcentrifuge tube. The inoculum was atraumatically deposited on the mucosal surface of the vaginal vault using using a pipettor with a blunt polypropylene pipette tip and was completely absorbed in approximately five minutes.

Inoculum dose was determined based upon the results of several mucosal inoculation studies. We have previously used a combined dose of $7.5 \times 10^{4} \mathrm{FIV}$ positive cells and $7.5 \times 10^{4}$ TCID $_{50}$ cell-free and infected $6 / 10$ control cats [74]. Other studies using the $\mathrm{NCSU}_{1}$ showed that all cats vaginally inoculated with $10^{4}-10^{6}$ FIV-positive cells became FIV-positive, whereas those infected with $10^{3}-10^{2}$ FIV-positive cells were either negative or latently positive [56]. Another study employing mucosal infection using a clade $B$ virus strain, found that cats inoculated with $2.0 \times 10^{5}$ but not $2.0 \times 10^{3} \mathrm{FIV}$-positive cells were infected three weeks post-inoculation [43]. Given the results of these studies, and a prior pilot study (data not shown), inoculum doses were chosen for this study, with approximately one log difference in dose from the high to low dose inoculums.

\section{Sample collection and processing}

Plasma, serum and vaginal wash fluids were collected at weeks $0,2,4,6$, and 8 post-infection and processed [83]. Peripheral blood mononuclear cells (PBMC), prescapular lymph node (PLN), mesenteric lymph node $(\mathrm{MLN})$, medial iliac lymph node (ILN), spleen, bone marrow and distal jejunum were harvested at necropsy. Blood for PBMC isolation was collected at weeks $0,2,4,6$, and 8 in ACD tubes, and isolated using Histopaque (Sigma, St Louis, MO) density centrifugation [52]. Lymph nodes, thymus [84] and spleens [85] were processed as previously described. Bone marrow collected from the femur was dissociated using mesh screens. After washing, pellets were lysed with ammonium chloride lysis buffer, washed twice and counted. Intraepithelial lymphocytes (IEL) and lamina propria lymphocytes (LPL) were isolated from distal jejunum following excision of Peyer's patches and lymphoid follicles, as previously described [84].

\section{Real-time FIV RNA PCR}

Real-time PCR to detect viral RNA in plasma was performed as previously described [86], with minor modifications. Real-time PCR was run on a Biorad MyIQ using continuous RT-PCR at $48^{\circ} \mathrm{C}$ for 30 minutes, $95^{\circ} \mathrm{C}$ for 10 minutes, followed by 45 cycles of $95^{\circ} \mathrm{C}$ for $10 \mathrm{sec}$ onds and $57.5^{\circ} \mathrm{C}$ for 1 minute. The limit of detection for this assay is $\leq 10$ copies per $45 \mu$ l of plasma.

\section{Real-time FIV DNA PCR}

Real time PCR was performed to quantify FIV provirus [87] using previously described primers and probe [86]. DNA was extracted using the DNeasy Tissue Kit (Qiagen, Valencia, CA). Real-time PCR reaction contained $300 \mathrm{nM}$ forward primer, $400 \mathrm{nM}$ reverse primer, and 80 nM probe, ABI Universal Mastermix (Applied Biosystems, Foster City, CA), water and DNA sample. The feline genome contains one copy of the CCR5 sequence and was used to normalize FIV copy number. The CCR5 primers (forward 5'-ACGTCTACCTGCTCAACCTGG-3', reverse 5'-ACCGTCTTACACATCCCATCCC-3') and probe (FAM-5'-TCCGACCTGCTCTTCCTCTTCACCCTCC-3') were designed using Beacon Designer. PCR reactions for CCR5 were run on a separate plate using $200 \mathrm{nM}$ forward primer, $500 \mathrm{nM}$ reverse primer, and $200 \mathrm{nM}$ probe, ABI Universal Master mix, water and DNA sample. FIV and CCR5 plates were run sequentially on the same instrument. All standard dilutions, controls and samples were run in duplicate. The limit of detection was $\leq 10$ copies of FIV per 1 $\mu \mathrm{g}$ DNA.

\section{Virus isolation}

Cryopreserved bone marrow samples were thawed, washed, counted and $1.5 \times 10^{5}$ co-cultured with 3.0 $\times 10^{5}$ FCD4-Ecells or Mya-1 cells, both of which are FIV susceptible cell lines, in triplicate in LBT medium supplemented with $100 \mathrm{U} / \mathrm{ml}$ recombinant human IL-2 (AIDS Research and Reference Reagent Program, Division of AIDS, NIAID, NIH: contributed by Hoffman-La Roche Inc.). Supernatants were analyzed for FIV p24 by antigen capture ELISA at 16 and 20 days of culture [52]. In addition, cells were analyzed for intracellular viral antigen by FACS at 20 days of culture using the BD Cytofix/Cytoperm kit and FITC conjugated anti-FIV monoclonal antibody 43-1B9. 


\section{Monoclonal antibodies}

Monoclonal antibodies (mAb) used for cell surface staining were directly conjugated to FITC, PE, biotin, PerCP, APC, PECy7, or Alexa 700. Previously described antibodies included anti-CD4 (3-4F4), antiCD8 $\alpha$ (3.357), Streptavidin-PerCP, and StreptavidinAPC [84]. Other antibodies included anti-feline CD8 $\beta$ and Streptavidin-Pe-Cy7 (Southern Biotechnology, Birmingham, AL); anti-CD56 (clone C5.9, Dako, Carpinteria, CA); anti-tumor necrosis factor alpha (TNF $\alpha$, clone 6401.1111, BD Biosciences, San Jose, CA); antiinterleukin-2 (IL2, clone MQ1-17H12, Biolegend, San Diego, CA), and anti-interferon gamma (IFN $\gamma$, clone E4A3B9) made in our laboratory. Anti-feline CD3 (clone NZM1), a generous gift from T. Miyazawa (Univ. of Tokyo, Japan) detected with anti-mouse IgG3 APC (\#115-135-209, Jackson Immunoresearch, West Grove, PA). Staining and flow cytometric analysis were performed as previously described [84]. Samples were fixed with $4 \%$ paraformaldehyde, collected on a BD LSRII (BD Immunocytometry Systems, San Jose, CA) flow cytometer, and analyzed with BD FACS Diva software.

\section{Intracellular cytokine production}

PBMC, spleen, PLN, ILN, IEL and LPL were cultured overnight in LBT medium without stimulation. Cells were then stimulated with either Gag or Env peptide pools, Con A, or media alone for six hours, with $1.5 \mu \mathrm{l} /$ $\mathrm{ml}$ of $1 \mathrm{x}$ Monensin (Biolegend, San Diego, CA) present for the final five hours. Following culture, cells were washed with PBS and stained with antibodies to CD4 and CD8, washed, and fixed with $4 \%$ paraformaldehyde (PFA) for ten minutes, then washed and resuspended in PBS $/ 2 \%$ FBS, covered and stored at $-4^{\circ} \mathrm{C}$. Within 24-48 hours of PFA fixation, cells were washed with Perm/ Wash Buffer (BD Cytofix/Cytoperm), stained with antibodies to IFN $\gamma$, IL-2, and TNF $\alpha$ for 30 minutes, washed and analyzed immediately, collecting 100,000 gated events whenever possible. For analysis, cell populations were initially gated to identify the viable leukocyte population on FSC and SSC. Using this gate, CD4+ and CD8 $+\mathrm{T}$ cells were individually gated and CD4+ and CD8+ $\mathrm{T}$ cells producing IL-2, IFN $\gamma$ and TNF $\alpha$ in response to Gag or Env peptide stimulation identified (Additional file 1). The percentage of $\mathrm{T}$ cells responding to stimulation was calculated by subtracting the cytokine response detected in cells from the same sample stimulated with media alone.

FIV p24 antibody chemiluminescent ELISA

Chromalux $^{\mathrm{TM}}$ HB Luminescent Assay microplates (Dynex Technologies Inc., Chantilly, VA) were coated with $1.0 \mu \mathrm{g} / \mathrm{ml}$ p24-GST fusion protein [88] and ELISA completed as previously described [89] with minor modifications. Blocking buffer contained CBC buffer with $5 \%$ nonfat dry milk and $0.1 \%$ Kathon. ELISA wash buffer (EWB) contained PBS, $0.05 \%$ Tween-20, and $0.1 \%$ Kathon. Samples were serially diluted in sample diluent (PBS, 5\% non-fat dry milk, $5 \%$ goat serum, $0.05 \%$ Tween- 20 and $0.1 \%$ Kathon), added to ELISA plates at $100 \mu \mathrm{l} /$ well, covered and incubated for three hours at $37^{\circ} \mathrm{C}$, then washed six times with EWB. Antibody was detected with goat anti-cat IgG (Bethyl Labs, Montgomery, TX) or goat anti-IgA (Serotec, Raleigh, NC) diluted 1:80,000 and $1: 3,000$ respectively in sample diluent, covered, incubated one hour at $25^{\circ} \mathrm{C}$, then washed six times with EWB. Plates were developed with $100 \mu \mathrm{l} /$ well Pierce SuperSignal ELISA Femto Chemiluminescent substrate \#37074 and read five minutes after addition of substrate (Perkin-Elmer Victor 31420 Multilabel Counter). Antibody titers were considered positive if they were two-fold greater than the naïve serum/vaginal wash sample for the same individual.

\section{FIV Env antibody chemiluminescent ELISA}

Anti-envelope responses were measured using a previously described envelope fusion protein (gp95-FC) [90]. Anti-Env ELISA was completed as described for anti-p24 antibody ELISA with minor modifications. Blocking buffer contained CBC buffer with $3 \%$ non-fat dry milk, $5 \%$ goat serum, and $0.1 \%$ Kathon. Sample diluent contained PBS, 1\% BSA, 1\% non-fat dry milk, $2.5 \%$ human serum, $0.05 \%$ Tween-20 and $0.1 \%$ Kathon. Plates were coated with $100 \mu \mathrm{l} /$ well of gp95-FC at $2.5 \mu \mathrm{g} / \mathrm{ml}$ in sample diluent. Sample dilutions were incubated for 30 minutes at $25^{\circ} \mathrm{C}$ prior to loading $100 \mu \mathrm{l} /$ well to ELISA plates. Secondary antibodies for anti-IgG and anti-IgA detection were diluted to $1: 60,000$ and $1: 3,000$ respectively.

\section{Statistical analysis}

Comparison of viremic versus non-viremic FIV inoculated cats was completed using an unpaired t-test. Statistical analysis of differentially FIV-inoculated groups and control cats utilized a one-way analysis of variance (ANOVA) with a Tukey-Kramer multiple comparison post-test or nonparametric ANOVA (Kruskal-Wallis test) with Dunn's multiple comparison post-test. The choice of test was dictated by testing the assumptions necessary for parametric methods, such that if a parametric method was not appropriate, non-parametric testing was used. Significance was defined as $\mathrm{p} \leq 0.05$. Analyses were completed using GraphPad InStat version 3.05 (GraphPad Software, San Diego, CA). 
Additional File 1: Supplemental Figure 1. Gating strategy for intracellular cytokine assessment. Samples stained for surface and intracellular antigens were gated based on forward and side scatter (A). The gated population was used to identify CD4+ and CD8+ T cells (B). Using either $\mathrm{CD} 4+$ or $\mathrm{CD} 8+\mathrm{T}$ cells as the parent gate, specific staining for IFNy (y-axis) and IL-2 (x-axis) are shown for unstimulated (C) and stimulated samples (D) from the same medial iliac lymph node. For analysis, the percent of cells staining positively in unstimulated samples was subtracted from stimulated samples to determine net cytokine production reported in Figure 6 .

Click here for file

[ http://www.biomedcentral.com/content/supplementary/1742-4690-7-2S1.BMP ]

\section{Acknowledgements}

We thank Dr. Shila Nordone for her assistance in developing the chemiluminescent ELISA assays and Dr. Susan Lankford for her assistance with real-time FIV DNA PCR. We also thank Chasity Jones and Emily Smith for their technical assistance. This study was funded by NIH/NIAID R21Al065223 (GD) and NIH/NIAID K08 Al056984 (KH).

\section{Author details}

${ }^{1}$ Center for Comparative Medicine and Translational Research, Department of Molecular Biomedical Sciences, College of Veterinary Medicine, North Carolina State University, Raleigh, NC, 27606, USA. ${ }^{2}$ Current address: Immunobio, 920 Main Campus Drive, Suite 405, Raleigh, NC, 27606, USA.

\section{Authors' contributions}

$\mathrm{KH}$ designed and coordinated the study, collected and processed biological samples, performed FACS assays and virus isolation, analyzed data, performed statistical analysis and drafted the manuscript. SR helped design the study, collected and processed biological samples, performed FACS assays and assisted in data analysis. EE collected and processed biological samples, performed PCR and ELISA assays and assisted in data analysis. GD helped design the study, critically reviewed the results and helped to draft the manuscript. All authors read and approved the final manuscript.

\section{Competing interests}

The authors declare that they have no competing interests.

\section{Received: 4 August 2009}

Accepted: 19 January 2010 Published: 19 January 2010

\section{References}

1. HIV vaccine failure prompts Merck to halt trial. Nature 2007, 449:390

2. Vaccine trial discontinued. AIDS Patient Care STDS 2007, 21:778-779.

3. Cohen J: AIDS research. Promising AIDS vaccine's failure leaves field reeling. Science 2007, 318:28-29.

4. Priddy FH, Brown D, Kublin J, Monahan K, Wright DP, Lalezari J, Santiago S, Marmor M, Lally M, Novak RM, Brown SJ, Kulkarni P, Dubey SA, Kierstead LS, Casimiro DR, Mogg R, DiNubile MJ, Shiver JW, Leavitt RY, Robertson MN, Mehrotra DV, Quirk E, Merck V520-016 Study Group: Safety and immunogenicity of a replication-incompetent adenovirus type 5 HIV-1 clade B gag/pol/nef vaccine in healthy adults. Clin Infect Dis 2008, 46:1769-1781.

5. Buchbinder SP, Mehrotra DV, Duerr A, Fitzgerald DW, Mogg R, Li D, Gilbert PB, Lama JR, Marmor M, Del Rio C, McElrath MJ, Casimiro DR, Gottesdiener KM, Chodakewitz JA, Corey L, Robertson MN, Step Study Protocol Team: Efficacy assessment of a cell-mediated immunity HIV-1 vaccine (the Step Study): a double-blind, randomised, placebocontrolled, test-of-concept trial. Lancet 2008, 372:1881-1893.

6. Heeney JL, Plotkin SA: Immunological correlates of protection from HIV infection and disease. Nat Immunol 2006, 7:1281-1284.

7. Betts MR, Nason MC, West SM, De Rosa SC, Migueles SA, Abraham J, Lederman MM, Benito JM, Goepfert PA, Connors M, Roederer M, Koup RA: HIV nonprogressors preferentially maintain highly functional HIV-specific CD8+ T cells. Blood 2006, 107:4781-4789.
8. Kaul R, Rowland-Jones SL, Kimani J, Fowke K, Dong T, Kiama P, Rutherford J, Njagi E, Mwangi F, Rostron T, Onyango J, Oyugi J, MacDonald KS, Bwayo JJ, Plummer FA: New insights into HIV-1 specific cytotoxic T-lymphocyte responses in exposed, persistently seronegative Kenyan sex workers. Immunol Lett 2001, 79:3-13.

9. Addo MM, Draenert R, Rathod A, Verrill CL, Davis BT, Gandhi RT, Robbins GK, Basgoz NO, Stone DR, Cohen DE, Johnston MN, Flynn T, Wurcel AG, Rosenberg ES, Altfeld M, Walker BD: Fully differentiated HIV-1 specific CD8+ T effector cells are more frequently detectable in controlled than in progressive HIV-1 infection. PLOS ONE 2007, 2:e321.

10. Gea-Banacloche JC, Migueles SA, Martino L, Shupert WL, MCNeil AC, Sabbaghian MS, Ehler L, Prussin C, Stevens R, Lambert L, Altman J, Hallahan CW, de Quiros JC, Connors M: Maintenance of large numbers of virus-specific CD8+ T cells in HIV-infected progressors and long-term nonprogressors. J Immunol 2000, 165:1082-1092.

11. Lamine A, Caumont-Sarcos A, Chaix ML, Saez-Cirion A, Rouzioux C, Delfraissy JF, Pancino G, Lambotte O: Replication-competent HIV strains infect HIV controllers despite undetectable viremia (ANRS EP36 study). Aids 2007, 21:1043-1045.

12. Saez-Cirion $A$, Lacabaratz $C$, Lambotte $O$, Versmisse $P$, Urrutia $A$, Boufassa $F$, Barre-Sinoussi F, Delfraissy JF, Sinet M, Pancino G, Venet A: HIV controllers exhibit potent CD8 T cell capacity to suppress HIV infection ex vivo and peculiar cytotoxic T lymphocyte activation phenotype. Proc Natl Acad Sci USA 2007, 104:6776-6781.

13. Hladik F, Desbien A, Lang J, Wang L, Ding Y, Holte S, Wilson A, Xu Y, Moerbe M, Schmechel S, McElrath MJ: Most highly exposed seronegative men lack HIV-1-specific, IFN-gamma-secreting T cells. J Immunol 2003, 171:2671-2683.

14. Mansfield K, Lang SM, Gauduin MC, Sanford HB, Lifson JD, Johnson RP, Desrosiers RC: Vaccine protection by live, attenuated simian immunodeficiency virus in the absence of high-titer antibody responses and high-frequency cellular immune responses measurable in the periphery. J Virol 2008, 82:4135-4148.

15. Nguyen M, Pean P, Lopalco L, Nouhin J, Phoung V, Ly N, Vermisse P, Henin Y, Barre-Sinoussi F, Burastero SE, Reynes JM, Carcelain G, Pancino G: HIV-specific antibodies but not t-cell responses are associated with protection in seronegative partners of HIV-1-infected individuals in Cambodia. J Acquir Immune Defic Syndr 2006, 42:412-419.

16. Schmechel SC, Russell N, Hladik F, Lang J, Wilson A, Ha R, Desbien A, McElrath MJ: Immune defence against HIV-1 infection in HIV-1-exposed seronegative persons. Immunol Lett 2001, 79:21-27.

17. Sadoff JC, Wittes J: Correlates, surrogates, and vaccines. J Infect Dis 2007, 196:1279-1281.

18. Qin L, Gilbert PB, Corey L, McElrath MJ, Self SG: A framework for assessing immunological correlates of protection in vaccine trials. J Infect Dis 2007, 196:1304-1312.

19. Casimiro DR, Wang F, Schleif WA, Liang X, Zhang ZQ, Tobery TW, Davies ME, McDermott AB, O'Connor DH, Fridman A, Bagchi A, Tussey LG, Bett AJ, Finnefrock AC, Fu TM, Tang A, Wilson KA, Chen M, Perry HC, Heidecker GJ, Freed DC, Carella A, Punt KS, Sykes KJ, Huang L, Ausensi VI, Bachinsky M, Sadasivan-Nair U, Watkins DI, Emini EA, Shiver JW: Attenuation of simian immunodeficiency virus SIVmac239 infection by prophylactic immunization with dna and recombinant adenoviral vaccine vectors expressing Gag. J Virol 2005, 79:15547-15555.

20. Wilson NA, Reed J, Napoe GS, Piaskowski S, Szymanski A, Furlott J, Gonzalez EJ, Yant L, Maness NJ, May GE, Soma T, Reynolds MR, Rakasz E, Rudersdorf R, McDermott AB, O'Connor DH, Friedrich TC, Allison DB, Patki A, Picker LJ, Burton DR, Lin J, Huang L, Patel D, Heindecker G, Fan J, Citron M, Horton M, Wang F, Liang X, Shiver JW, Casimiro DR, Watkins DI: Vaccineinduced cellular immune responses reduce plasma viral concentrations after repeated low-dose challenge with pathogenic simian immunodeficiency virus SIVmac239. J Virol 2006, 80:5875-5885.

21. Mattapallil JJ, Douek DC, Buckler-White A, Montefiori D, Letvin NL, Nabel GJ, Roederer M: Vaccination preserves CD4 memory T cells during acute simian immunodeficiency virus challenge. J Exp Med 2006, 203:1533-1541.

22. Buge SL, Murty L, Arora K, Kalyanaraman VS, Markham PD, Richardson ES, Aldrich K, Patterson $\amalg$, Miller CJ, Cheng SM, Robert-Guroff M: Factors associated with slow disease progression in macaques immunized with an adenovirus-simian immunodeficiency virus (SIV) envelope priminggp120 boosting regimen and challenged vaginally with SIVmac251. J Virol 1999, 73:7430-7440. 
23. Shiver JW, Fu TM, Chen L, Casimiro DR, Davies ME, Evans RK, Zhang ZQ, Simon AJ, Trigona WL, Dubey SA, Huang L, Harris VA, Long RS, Liang $X$, Handt L, Schleif WA, Zhu L, Freed DC, Persaud NV, Guan L, Punt KS, Tang A, Chen M, Wilson KA, Collins KB, Heidecker GJ, Fernandez VR, Perry HC, Joyce JG, Grimm KM, Cook JC, Keller PM, Kresock DS, Mach H, Troutman RD, Isopi LA, Williams DM, Xu Z, Bohannon KE, Volkin DB, Montefiori DC, Miura A, Krivulka GR, Lifton MA, Kuroda MJ, Schmitz JE, Letvin NL, Caulfield MJ, Bett AJ, Youil R, Kaslow DC, Emini EA: Replicationincompetent adenoviral vaccine vector elicits effective antiimmunodeficiency-virus immunity. Nature 2002, 415:331-335.

24. Regoes RR, Longini IM, Feinberg MB, Staprans SI: Preclinical assessment of HIV vaccines and microbicides by repeated low-dose virus challenges. PLOS Med 2005, 2:e249.

25. AIDS Epidemic Update:December 2008. WHO/UNAIDS Joint United Nations Programme on HIV/AIDS 2008.

26. Wilson DP, Law MG, Grulich AE, Cooper DA, Kaldor JM: Relation between HIV viral load and infectiousness: a model-based analysis. Lancet 2008, 372:314-320.

27. Kaizu M, Weiler AM, Weisgrau KL, Vielhuber KA, May G, Piaskowski SM, Furlott J, Maness NJ, Friedrich TC, Loffredo JT, Usborne A, Rakasz EG: Repeated intravaginal inoculation with cell-associated simian immunodeficiency virus results in persistent infection of nonhuman primates. J Infect Dis 2006, 194:912-916.

28. Ma ZM, Abel K, Rourke T, Wang Y, Miller CJ: A period of transient viremia and occult infection precedes persistent viremia and antiviral immune responses during multiple low-dose intravaginal simian immunodeficiency virus inoculations. J Virol 2004, 78:14048-14052.

29. McDermott AB, Mitchen J, Piaskowski S, De Souza I, Yant LJ, Stephany J, Furlott J, Watkins DI: Repeated low-dose mucosal simian immunodeficiency virus SIVmac239 challenge results in the same viral and immunological kinetics as high-dose challenge: a model for the evaluation of vaccine efficacy in nonhuman primates. J Virol 2004, 78:3140-3144.

30. Assogba BD, Leavell S, Porter K, Burkhard MJ: Mucosal administration of low-dose cell-associated feline immunodeficiency virus promotes viral latency. J Infect Dis 2007, 195:1184-1188.

31. McChesney MB, Collins JR, Lu D, Lu X, Torten J, Ashley RL, Cloyd MW, Miller $\mathrm{CJ}$ : Occult systemic infection and persistent simian immunodeficiency virus (SIV)-specific CD4(+)-T-cell proliferative responses in rhesus macaques that were transiently viremic after intravaginal inoculation of SIV. J Virol 1998, 72:10029-10035.

32. Zhu T, Corey L, Hwangbo Y, Lee JM, Learn GH, Mullins Jl, McElrath MJ: Persistence of extraordinarily low levels of genetically homogeneous human immunodeficiency virus type 1 in exposed seronegative individuals. J Virol 2003, 77:6108-6116.

33. Nicastri E, Ercoli L, Sarmati $L$, d'Ettorre G, ludicone P, Massetti P, Vullo V, Andreoni M: Human immunodeficiency virus-1 specific and natural cellular immunity in HIV seronegative subjects with multiple sexual exposures to virus. J Med Virol 2001, 64:232-237.

34. Pereyra F, Addo MM, Kaufmann DE, Liu Y, Miura T, Rathod A, Baker B, Trocha A, Rosenberg R, Mackey E, Ueda P, Lu Z, Cohen D, Wrin T, Petropoulos CJ, Rosenberg ES, Walker BD: Genetic and immunologic heterogeneity among persons who control HIV infection in the absence of therapy. J Infect Dis 2008, 197:563-571.

35. Tompkins MB, Nelson PD, English RV, Novotney C: Early events in the immunopathogenesis of feline retrovirus infections. J Am Vet Med Assoc 1991, 199:1311-1315.

36. English RV, Nelson P, Johnson CM, Nasisse M, Tompkins WA, Tompkins MB: Development of clinical disease in cats experimentally infected with feline immunodeficiency virus. J Infect Dis 1994, 170:543-552.

37. Sparkes AH, Hopper CD, Millard WG, Gruffydd-Jones TJ, Harbour DA: Feline immunodeficiency virus infection. Clinicopathologic findings in 90 naturally occurring cases. J Vet Intern Med 1993, 7:85-90.

38. Obert LA, Hoover EA: Feline immunodeficiency virus clade $C$ mucosal transmission and disease courses. AIDS Res Hum Retroviruses 2000, 16:677-688.

39. Allison RW, Hoover EA: Covert vertical transmission of feline immunodeficiency virus. AIDS Res Hum Retroviruses 2003, 19:421-434.

40. Dean GA, LaVoy A, Burkhard MJ: Peptide mapping of feline immunodeficiency virus by IFN-gamma ELISPOT. Vet Immunol Immunopathol 2004, 100:49M-59.
41. Krieger JN, Coombs RW, Collier AC, Ross SO, Chaloupka K, Cummings DK, Murphy VL, Corey L: Recovery of human immunodeficiency virus type 1 from semen: minimal impact of stage of infection and current antiviral chemotherapy. Infect Dis J 1991, 163:386-388.

42. Plummer FA, Simonsen JN, Cameron DW, Ndinya-Achola JO, Kreiss JK, Gakinya MN, Waiyaki $P$, Cheang M, Piot P, Ronald AR, et al: Cofactors in male-female sexual transmission of human immunodeficiency virus type 1. J Infect Dis 1991, 163:233-239.

43. Spinillo A, Zara F, De Santolo A, Brerra R, Maserati R, Romero E, Filice G: Quantitative assessment of cell-associated and cell-free virus in cervicovaginal samples of HIV-1-infected women. Clin Microbiol Infect 1999, 5:605-611.

44. Politch JA, Wolff $H$, Hill JA, Anderson DJ: Comparison of methods to enumerate white blood cells in semen. Fertil Steril 1993, 60:372-375.

45. Wolff $H$, Anderson DJ: Male genital tract inflammation associated with increased numbers of potential human immunodeficiency virus host cells in semen. Andrologia 1988, 20:404-410.

46. Wolff $H$, Anderson DJ: Immunohistologic characterization and quantitation of leukocyte subpopulations in human semen. Fertil Steril 1988, 49:497-504.

47. Shacklett BL: Understanding the "lucky few": the conundrum of HIVexposed, seronegative individuals. Curr HIV/AIDS Rep 2006, 3:26-31.

48. Dandekar S, Beebe AM, Barlough J, Phillips T, Elder J, Torten M, Pedersen N: Detection of feline immunodeficiency virus (FIV) nucleic acids in FIVseronegative cats. J Virol 1992, 66:4040-4049.

49. Sandy JR, Robinson WF, Bredhauer B, Kyaw-Tanner M, Howlett CR: Productive infection of the bone marrow cells in feline immunodeficiency virus infected cats. Arch Virol 2002, 147:1053-1059.

50. Rojko JL, Hoover EA, Quackenbush SL, Olsen RG: Reactivation of latent feline leukaemia virus infection. Nature 1982, 298:385-388.

51. Siebelink KH, Chu IH, Rimmelzwaan GF, Weijer K, Osterhaus AD, Bosch ML: Isolation and partial characterization of infectious molecular clones of feline immunodeficiency virus obtained directly from bone marrow DNA of a naturally infected cat. J Virol 1992, 66:1091-1097.

52. Stevens R, Howard KE, Nordone S, Burkhard M, Dean GA: Oral immunization with recombinant listeria monocytogenes controls virus load after vaginal challenge with feline immunodeficiency virus. J Virol 2004, 78:8210-8218.

53. Sahu GK, Chen JJ, Huang JC, Ramsey KM, Cloyd MW: Transient or occult HIV-1 infection in high-risk adults. Aids 2001, 15:1175-1177.

54. Sahu GK, McNearney T, Evans A, Turner A, Weaver S, Huang JC, Baron S, Paar D, Cloyd MW: Transient or occult HIV infections may occur more frequently than progressive infections: changing the paradigm about HIV persistence. Arch Virol Suppl 2005, 131-145.

55. Tenenbaum SA, Morris CA, Alexander SS, McFerrin HE, Garry RF, Leissinger CA: Evidence of HIV exposure and transient seroreactivity in archived HIV-negative severe hemophiliac sera. Virol J 2005, 2:65.

56. Uberla K: HIV vaccine development in the aftermath of the STEP study: re-focus on occult HIV infection?. PLoS Pathog 2008, 4:e1000114.

57. Fortis C, Poli G: Dendritic cells and natural killer cells in the pathogenesis of HIV infection. Immunol Res 2005, 33:1-21.

58. Alter $G$, Altfeld M: NK cells in HIV-1 infection: evidence for their role in the control of HIV-1 infection. J Intern Med 2009, 265:29-42.

59. Scott-Algara D, Truong LX, Versmisse P, David A, Luong T, Nguyen NV, Theodorou I, Barre-Sinoussi F, Pancino G: Cutting edge: increased NK cell activity in HIV-1-exposed but uninfected Vietnamese intravascular drug users. J Immunol 2003, 171:5663-5667.

60. O'Connell KA, Han Y, Williams TM, Siliciano RF, Blankson JN: Role of natural killer cells in a cohort of elite suppressors: low frequency of the protective KIR3DS1 allele and limited inhibition of human immunodeficiency virus type 1 replication in vitro. J Virol 2009, 83:5028-5034.

61. Emu B, Sinclair E, Favre D, Moretto WJ, Hsue P, Hoh R, Martin JN, Nixon DF, McCune JM, Deeks SG: Phenotypic, functional, and kinetic parameters associated with apparent T-cell control of human immunodeficiency virus replication in individuals with and without antiretroviral treatment. J Virol 2005, 79:14169-14178.

62. Daucher M, Price DA, Brenchley JM, Lamoreaux L, Metcalf JA, Rehm C, NiesKraske E, Urban E, Yoder C, Rock D, Gumkowski J, Betts MR, Dybul MR, Douek DC: Virological Outcome After Structured Interruption of Antiretroviral Therapy For HIV Infection is Associated with the 
Functional Profile of Virus-Specific CD8+ T-Cells. J Virol 2008, 82:4102-4114.

63. Pahar B, Lackner AA, Piatak M Jr, Lifson JD, Wang X, Das A, Ling B, Montefiori DC, Veazey RS: Control of viremia and maintenance of intestinal CD4(+) memory T cells in SHIV(162P3) infected macaques after pathogenic SIV(MAC251) challenge. Virology 2009, 387:273-284.

64. Barry AP, Silvestri G, Safrit JT, Sumpter B, Kozyr N, McClure HM, Staprans SI, Feinberg MB: Depletion of CD8+ cells in sooty mangabey monkeys naturally infected with simian immunodeficiency virus reveals limited role for immune control of virus replication in a natural host species. $J$ Immunol 2007, 178:8002-8012.

65. Schellens IM, Borghans JA, Jansen CA, De Cuyper IM, Geskus RB, van Baarle D, Miedema F: Abundance of early functional HIV-specific CD8+ T cells does not predict AIDS-free survival time. PLoS One 2008, 3:e2745.

66. Jiao Y, Xie J, Li T, Han Y, Qiu Z, Zuo L, Wang A: Correlation between gagspecific CD8 T-cell responses, viral load, and CD4 count in HIV-1 infection is dependent on disease status. J Acquir Immune Defic Syndr 2006, 42:263-268.

67. Smith SM, Holland B, Russo C, Dailey PJ, Marx PA, Connor Rl: Retrospective analysis of viral load and SIV antibody responses in rhesus macaques infected with pathogenic SIV: predictive value for disease progression. AIDS Res Hum Retroviruses 1999, 15:1691-1701.

68. Beer BE, Brown CR, Whitted S, Goldstein S, Goeken R, Plishka R, BucklerWhite A, Hirsch VM: Immunodeficiency in the absence of high viral load in pig-tailed macaques infected with Simian immunodeficiency virus SIVsun or SIVlhoest. J Virol 2005, 79:14044-14056.

69. Staprans SI, Barry AP, Silvestri G, Safrit JT, Kozyr N, Sumpter B, Nguyen H, McClure H, Montefiori D, Cohen Jl, Feinberg MB: Enhanced SIV replication and accelerated progression to AIDS in macaques primed to mount a CD4 T cell response to the SIV envelope protein. Proc Natl Acad Sci USA 2004, 101:13026-13031.

70. Bruck C, Thiriart C, Fabry L, Francotte M, Pala P, Van Opstal O, Culp J, Rosenberg M, De Wilde M, Heidt P, Heeney J: HIV-1 envelope-elicited neutralizing antibody titres correlate with protection and virus load in chimpanzees. Vaccine 1994, 12:1141-1148.

71. Cao Y, Qin L, Zhang L, Safrit J, Ho DD: Virologic and immunologic characterization of long-term survivors of human immunodeficiency virus type 1 infection. N Engl J Med 1995, 332:201-208.

72. Harrer T, Harrer E, Kalams SA, Elbeik T, Staprans SI, Feinberg MB, Cao Y, Ho DD, Yilma T, Caliendo AM, Johnson RP, Buchbinder SP, Walker BD: Strong cytotoxic $\mathrm{T}$ cell and weak neutralizing antibody responses in a subset of persons with stable nonprogressing HIV type 1 infection. AIDS Res Hum Retroviruses 1996, 12:585-592.

73. Montefiori DC, Pantaleo G, Fink LM, Zhou JT, Zhou JY, Bilska M, Miralles GD, Fauci AS: Neutralizing and infection-enhancing antibody responses to human immunodeficiency virus type 1 in long-term nonprogressors. $J$ Infect Dis 1996, 173:60-67.

74. Bailey JR, Lassen KG, Yang HC, Quinn TC, Ray SC, Blankson JN, Siliciano RF: Neutralizing antibodies do not mediate suppression of human immunodeficiency virus type 1 in elite suppressors or selection of plasma virus variants in patients on highly active antiretroviral therapy. Virol 2006, 80:4758-4770.

75. Brenchley JM, Schacker TW, Ruff LE, Price DA, Taylor JH, Beilman GJ, Nguyen PL, Khoruts A, Larson M, Haase AT, Douek DC: CD4+ T cell depletion during all stages of HIV disease occurs predominantly in the gastrointestinal tract. J Exp Med 2004, 200:749-759.

76. Mattapallil JJ, Douek DC, Hill B, Nishimura Y, Martin M, Roederer M: Massive infection and loss of memory CD4+ T cells in multiple tissues during acute SIV infection. Nature 2005, 434:1093-1097.

77. Mehandru S, Poles MA, Tenner-Racz K, Horowitz A, Hurley A, Hogan C, Boden D, Racz P, Markowitz M: Primary HIV-1 infection is associated with preferential depletion of $\mathrm{CD} 4+\mathrm{T}$ lymphocytes from effector sites in the gastrointestinal tract. J Exp Med 2004, 200:761-770.

78. Veazey RS, DeMaria M, Chalifoux LV, Shvetz DE, Pauley DR, Knight HL, Rosenzweig M, Johnson RP, Desrosiers RC, Lackner AA: Gastrointestinal tract as a major site of CD4+ T cell depletion and viral replication in SIV infection. Science 1998, 280:427-431.

79. Brenchley JM, Price DA, Schacker TW, Asher TE, Silvestri G, Rao S, Kazzaz Z, Bornstein E, Lambotte O, Altmann D, Blazar BR, Rodriguez B, TeixeiraJohnson L, Landay A, Martin JN, Hecht FM, Picker LJ, Lederman MM,
Deeks SG, Douek DC: Microbial translocation is a cause of systemic immune activation in chronic HIV infection. Nat Med 2006, 12:1365-1371.

80. Sankaran S, George MD, Reay E, Guadalupe M, Flamm J, Prindiville T, Dandekar S: Rapid onset of intestinal epithelial barrier dysfunction in primary human immunodeficiency virus infection is driven by an imbalance between immune response and mucosal repair and regeneration. J Virol 2008, 82:538-545.

81. Howard KE, Burkhard MJ: Mucosal challenge with cell-associated or cellfree feline immunodeficiency virus induces rapid and distinctly different patterns of phenotypic change in the mucosal and systemic immune systems. Immunology 2007, 122:571-583.

82. Pandrea IV, Gautam R, Ribeiro RM, Brenchley JM, Butler IF, Pattison M, Rasmussen T, Marx PA, Silvestri G, Lackner AA, Perelson AS, Douek DC, Veazey RS, Apetrei C: Acute loss of intestinal CD4+ T cells is not predictive of simian immunodeficiency virus virulence. J Immunol 2007, 179:3035-3046.

83. Burkhard MJ, Mathiason CK, Bowdre T, Hoover EA: Feline immunodeficiency virus Gag- and Env-specific immune responses after vaginal versus intravenous infection. AIDS Res Hum Retroviruses 2001, 17:1767-1778.

84. Howard KE, Fisher IL, Dean GA, Burkhard MJ: Methodology for isolation and phenotypic characterization of feline small intestinal leukocytes. J Immunol Methods 2005, 302:36-53.

85. Ignacio G, Nordone $\mathrm{S}$, Howard KE, Dean GA: Toll-like receptor expression in feline lymphoid tissues. Vet Immunol Immunopathol 2005, 106:229-237.

86. Burkhard MJ, Valenski L, Leavell S, Dean GA, Tompkins WA: Evaluation of FIV protein-expressing VEE-replicon vaccine vectors in cats. Vaccine 2002, 21:258-268.

87. Pedersen NC, Leutenegger CM, Woo J, Higgins J: Virulence differences between two field isolates of feline immunodeficiency virus (FIVAPetaluma and FIV-CPGammar) in young adult specific pathogen free cats. Vet Immunol Immunopathol 2001, 79:53-67.

88. Reid G, Rigby MA, McDonald M, Hosie MJ, Neil JC, Jarrett O: Immunodiagnosis of feline immunodeficiency virus infection using recombinant viral p17 and p24. Aids 1991, 5:1477-1483.

89. Staats HF, Nichols WG, Palker TJ: Mucosal immunity to HIV-1: systemic and vaginal antibody responses after intranasal immunization with the HIV-1 C4/V3 peptide T1SP10 MN(A). J Immunol 1996, 157:462-472.

90. de Parseval A, Elder JH: Binding of recombinant feline immunodeficiency virus surface glycoprotein to feline cells: role of CXCR4, cell-surface heparans, and an unidentified non-CXCR4 receptor. J Virol 2001, 75:4528-4539.

doi:10.1186/1742-4690-7-2

Cite this article as: Howard et al:: Acute mucosal pathogenesis of feline immunodeficiency virus is independent of viral dose in vaginally infected cats. Retrovirology 2010 7:2.

\section{Submit your next manuscript to BioMed Central and take full advantage of:}

- Convenient online submission

- Thorough peer review

- No space constraints or color figure charges

- Immediate publication on acceptance

- Inclusion in PubMed, CAS, Scopus and Google Scholar

- Research which is freely available for redistribution

Submit your manuscript at www.biomedcentral.com/submit
C Biomed Central 